\title{
KLASIFIKASI PEMINATAN SISWA SMA MENGGUNAKAN METODE NAIVE BAYES
}

\author{
Husni Naparin ${ }^{1)}$ \\ 1) Mahasiswa Doktoral Universitas Pendidikan Sultan Idris Jurusan Artificial Intelligence Faculty of Art, \\ Computing, and Creative Industry \\ e-mail: naparinhusni@yahoo.co.id ${ }^{1)}$
}

\begin{abstract}
Abstrak
The Government through 2013 curriculum wants to prepare students who are ready earlier than expected to develop his talents, so that the government create a system of specialization of class $X$ with a variety of considerations which is considered very mature, with a value based on the level of the previous studies, the value of the psychological test, the data of interest, and value specialization. It is necessary to study to classify the high school students specialization 2013 curriculum, 2013. In this study, algorithm that used is Naive Bayes. Probability Bayes principle or principles is the principle that is based on the observation and focused on the use of traditional methods. Classification of Naive Bayes assumption that holds the relationship between independent features or attributes that make it more effective for the categorization, a simple, fast and produces a high degree of accuracy.

The step of research include data collection and testing of Naive Bayes algorithm. In this study, the dataset used is desirable student Department, the Department of the Results of Psychotest, average value of Mathematics of the students when they were in the first to the fifth semester of junior high school, Math test scores, the average value of IPA of the student when they were in the first to the fifth semester of junior high school, IPA test scores, the average value of IPS of the student when they were in the first to the fifth semester of junior high school and IPS test scores.

This study aims to determine the Clasification Results using Naive Bayes Method of determining the appropriate students' specialization on 2013 curriculum, based on data value of SMAN 2 Banjarmasin. The significance of this study can be used by the school to perform accurate algorithm as a tool to calssify the corresponding specialization in 2013 curriculum and to provide an overview and understanding of Naive Bayes prediction methods, as a case study of the value of all the students of SMAN 2 Banjarmasin andto determine their specialization and it is also expected to become a tool determines the appropriate specialization curriculum in 2013 for students of SMAN 2 Banjarmasin. The result of the try out by using Naïve Bayes method to assess high school students' specialization reached the assessment result that has the highest accuration level $99.47 \%$ and AUC value 1.000.
\end{abstract}

Key Words: High School Students Specialization, Naive Bayes MethodAbstract

\section{PENDAHULUAN}

\subsection{Latar Belakang Masalah}

Pilihan kelompok peminatan merupakan bagian penting dalam upaya pencapaian SKL, KI, dan KD oleh peserta didik. Hal ini dikarenakan ketepatan dalam memilih kelompok peminatan merupakan bagian dari rencana awal peserta didik untuk menentukan fakultas atau jurusan pada jenjang pendidikan selanjutnya yakni perguruan tinggi. Untuk membantu peserta didik mencapai berbagai kompetensi yang diharapkan, pemilihan kelompok peminatan menjadi bagian penting diusahakan setepat mungkin. Dengan demikian, matapelajaran yang diambil akan sesuai dengan minat dan kemampuan serta berdampak pada perkembangan fisik dan psikologisnya.

Berdasarkan Kurikulum 2013, peminatan Siswa SMA dimulai pada waktu kelas X, dengan pedoman peminatan berdasarkan Nilai rapot SMP,
Nilai UN SMP, Nilai Psikotest, Nilai Peminatan dan keinginan siswa yang bersangkutan.Peminatan berdasarkan kurikulum 2013 merupakan cara baru yang diharapkan bisa meningkatkan kemampuan kerja lebih cepat sesuai dengan kemampuan khusus yang dimilikinya. Nilai Rapot SMP siswa diharapkan menjadi bahan pertimbangan untuk menentukan peminatan yang tepat, beberapa siswa memiliki nilai yang rendah tetapi setiap kenaikan semester menunjukkan grafik peningkatan. Nilai UN siswa SMP merupakan salah satu faktor pendukung menentukan peminatan karena apabila nilai rapot cenderung meningkat setiap semester dan kemudian didukung dengan nilai hasil UN yang tinggi maka siswa memiliki kemampuan yang lebih, sedangkan apabila nilai rapot rendah namun nilai UN tinggi berarti nilai UN bukan merupakan pedoman utama ketika sekolah menentukan peminatan. Nilai Psikotest juga merupakan nilai kepribadian siswa, cenderung mengarah pola pikir 
yang sesuai dengan peminatan sehingga dari hasil psikotest dapat ditentukan peminatan yang tepat. Tes Peminatan yaitu tes yang akan dijalani siswa itu sendiri sesuai dengan jurusan yang diminati siswa itu sendiri, sehingga hasil tes tersebut menentukan tepat atau tidaknya peminatan yang telah dipilih sebelumnya. Oleh karena itu peminatan berdasarkan kurikulum 2013 mempertimbangkan banyak hal, peminatan pada kelas $\mathrm{X}$ juga bertujuan untuk membentuk mental siswa yang siap bersaing sesuai peminatan yang telah ditentukan.

Jadi kesimpulannya, menurut prinsip Bayes atau prinsip Probabilitas yaitu prinsip yang berdasarkan hasil observasi dan difokuskan pada proses pengklasifikasian mengggunakan metode Naive Bayes yang memegang asumsi akan hubungan antar fitur atau atributnya yang independen sehingga menjadikannya lebih efektif untuk kategorisasi, sederhana, cepat dan menghasilkan tingkat akurasi yang tinggi.

\subsection{Rumusan Masalah}

Rumusan masalah pada penelitian ini adalah:"Bagaimana Hasil Klasifikasi Penggunaan Metode Naive Bayes menentukan peminatan siswa sesuai kurikulum 2013, berdasarkan data nilai siswa SMAN 2 Banjarmasin?

\subsection{Tujuan Penelitian}

Penelitian ini bertujuan untuk mengetahui Hasil Klasifikasi Penggunaan Metode Naive Bayes menentukan peminatan siswa sesuai kurikulum 2013, berdasarkan data nilai siswa SMAN 2 Banjarmasin.

\subsection{Manfaat penelitian \\ 1.4.1 Manfaat Praktis}

Manfaat hasil penelitian ini adalah agar pihak sekolah dapat menggunakan metode algoritma yang kinerjanya akurat sebagai alat untuk mengklasifikasi peminatan sesuai kurikulum 2013 berdasarkan klasifikasi nilai Akademik pada mata pelajaran tertentu di SMAN 2 Banjarmasin.

\subsubsection{Manfaat Teoritis}

Hasil penelitian ini diharapkan dapat memberikan gambaran dan pemahaman klasifikasi metode Naive Bayes,studi kasus nilai semua mata pelajaran siswa SMAN 2 Banjarmasin untuk menentukan peminatan sesuai dengan bakat yang dimiliki.

\section{1..4.3 Manfaat kebijakan}

Hasil penelitian ini diharapkan mampu menjadi alat bantu menentukan peminatan sesuai kurikulum 2013 bagi siswa SMAN 2
Banjarmasin.

\section{TINJAUAN PUSTAKA}

Kriteria Penjurusan Menurut Peraturan Perundangan

Data yang diperlukan untuk menetapkan peminatan peserta didik meliputi:

a. Data prestasi belajar peserta didik dari sekolah sebelumnya (SMP/MTs) kelasVII, VIII, dan IX dicermati perkembangan dan jumlah nilai setiap mata pelajaran terkait dengan peminatan belajar.

b. Data prestasi/nilai belajar UN dicermati relevansinya dengan peminatan dan nilai UN digabungkan dengan nilai rapor, sebagai pertimbangan menyusun ranking.

c. Data prestasi non akademik yang diperoleh dicermati relevansinya dengan peminatan dan dapat diberi score tingkat sekolah $=1$, kecamatan $=2$, kabupaten $=3$, provinsi $=4$, nasional $=5$, dan internasional $=7$. Pemberian skor ini diperlukan sebagai bahan menyusun ranking.

d. Data tentang minat studi lanjut, minat pekerjaan, minat jabatan, minat mata pelajaran, cita-cita kehidupan di masa depannya dan bidang peminatan yang dipilih, harus dicermati apakah terdapat relevansinya. Bila terdapat kesesuaian, maka mendukung untuk penetapan peminatan belajar peserta didik. Namun bila tidak relevan dengan peminatannya, maka dalam wawancara lebih ditekankan klarifikasi dan diberikan informasi yang memberikan wawasan lebih luas.

e. Data perhatian, fasilitasi, harapan, pendidikan, pekerjaan, sosial ekonomi orangtua diharapkan memberikan dukungan terhadap peminatan belajar peserta didik, terutama data tentang keinginan bidang keahlian diharapkan terdapat kesesuaian antara anak dan orang tua. Bila hasil pencermatan data orang tua peserta didik tidak memberikan dukungan terhadap peminatan belajar peserta didik, maka perlu dipahami lebih lanjut tentang perhatian orang tua melalui wawancara.. Dalam penetapan peminatan belajar perlu lebih mendasarkan pada data prestasi dan minat anak yang telah diperoleh dan ditambah hasil wawancara dan observasi.

f. Data deteksi potensi peserta didik di SMP/MTs atau rekomendasi Guru Bimbingan dan Konseling SMP/ MTs tentang peminatan belajar peserta didik.

g. Data deteksi potensi peserta didik melalui tes peminatan yang dilaksanakan di SMA/ SMK, akan diperoleh rekomendasi kecenderungan jenis peminatan belajar peserta didik.

\subsection{Data Mining}

Data mining merupakan data yang tersimpan dalam waktu yang lama kemudian data tersebut 


\section{SYSTEMIC}

Vol. 02, No. 01, Agustus 2016, 25-32

dikumpulkan, ternyata setelah di analisis data tersebut memiliki pola tertentu. Data mining biasanya berisi tentang statistik, ekonomi, ramalan cuaca serta berbagai jenis data lainnya yang berhubungan dengan pekerjaan. Data mining merupakan pelajaran apa yang telah terjadi dimasa lalu kemudian akan diterapkan dimasa yang akan datang agar memperoleh hasil yang lebih baik. Secara khusus, koleksi metode yang dikenal sebagai data mining menawarkan metodologi dan solusi teknis untuk mengatasi analisis data medis dan konstruksi prediksi model.

\subsection{Klasifikasi Data Mining}

Data mining mampu mengolah data dalam jumlah besar, setiap data terdiri dari kelas tertentu bersama dengan variabel dan faktor faktor penentu kelas variabel tersebut.

Secara umum sifat data mining adalah:

1. Predictive: menghasilkan model berdasarkan sekumpulan data yang dapat digunakan untuk memperkirakan nilai data yang lain. Metode yang termasuk dalam prediktif data mining adalah:

a. Klasifikasi: pembagian data ke dalam beberapa kelompok yang sudah ditentukan sebelumnya

b. Regresi: memetakan data ke suatu prediction variable

c. Rentet waktu: pengamatan perubahan nilai atribut dari waktu ke waktu

2. Descriptive: mengidentifikasi hubungan dalam data untuk menghasilkan informasi baru. Metode yang termasuk dalam Descriptive Data Mining adalah:

a. Clustering: identifikasi kategori untuk mendeskripsikan data

b. Association Rules: Identifikasi hubungan antar data yang satu dengan yang lainnya.

c. Summarization: pemetaan data ke dalam subset dengan deskripsi sederhana.

d. Sequence Discovery: identifikasi pola sekuensial dalam data

\subsection{Algoritma Naïve Bayes}

Algoritma Naive Bayes merupakan salah satu algoritma yang terdapat pada teknik klasifikasi. Naive Bayes merupakan pengklasifikasian dengan metode probabilitas dan statistik yang dikemukan oleh ilmuwan Inggris Thomas Bayes, yaitu memprediksi peluang di masa depan berdasarkan pengalaman dimasa sebelumnya sehingga dikenal sebagai Teorema Bayes. Teorema tersebut dikombinasikan dengan Naive dimana diasumsikan kondisi antar atribut saling bebas. Klasifikasi Naive Bayes diasumsikan bahwa ada atau tidak ciri tertentu dari sebuah kelas tidak ada hubungannya dengan ciri dari kelas lainnya.

Persamaan dari teorema Bayes adalah :
$\mathrm{P}(\mathrm{H} \mid \mathrm{X})=\frac{\mathrm{P}(\mathrm{X} \mid \mathrm{H}) \cdot \mathrm{P}(\mathrm{H})}{P(X)}$

Keterangan :

$\mathrm{X}$ : Data dengan class yang belum

diketahui

H : Hipotesis data X merupakan suatu class spesifik

$\mathrm{P}(\mathrm{H} \mid \mathrm{X})$ : Probabilitas hipotesis $\mathrm{H}$ berdasar

kondisi X (posterioriprobability)

$\mathrm{P}(\mathrm{H}) \quad$ : Probabilitas hipotesis $\mathrm{H}$ (prior

probability)

$\mathrm{P}(\mathrm{X} \mid \mathrm{H})$ : Probabilitas $\mathrm{X}$ berdasarkan kondisi

pada hipotesis $\mathrm{H}$

$\mathrm{P}(\mathrm{X})$ : Probabilitas $\mathrm{X}$

Untuk menjelaskan teorema Naive Bayes, perlu diketahui bahwa proses klasifikasi memerlukan sejumlah petunjuk untuk menentukan kelas apa yang cocok bagi sampel yang dianalisis tersebut. Karena itu, teorema Bayes di atas disesuaikan sebagai berikut.

$$
P(C \mid F 1 \ldots F n)=\frac{P(C) P(F 1 \ldots F n \| C)}{P(F 1 \ldots F n)}
$$

Rumus diatas dapat pula ditulis secara sederhana sebagai berikut :

Posterior $=\frac{\text { Prior } x \text { likehood }}{\text { evidence }}$

Nilai Evidence selalu tetap untuk setiap kelas pada satu sampel. Nilai dari posterior tersebut nantinya akan dibandingkan dengan nilai nilai posterior kelas lainnya untuk menentukan ke kelas apa suatu sampelakan diklasifikasikan. Penjabaran lebih lanjut rumus Bayes tersebut dilakukan dengan menjabarkan (C | F1 ...Fn ) menggunakan aturan perkalian sebagai berikut :

$$
\begin{aligned}
& P(C \mid F 1 \ldots F n)=P(C) P(F 1 \ldots F n \mid C) \\
& =P(C) P(F 1 \mid C) P(F 2, \ldots F n \mid C, F 1) \\
& =P \quad(C) \quad P \quad(F 1 \mid C) P \quad(F 2 \mid \quad C, F 1) \quad P \quad(F 3, \ldots F n \\
& \dashv \mid C, F 1, F 2) \\
& =P \quad(C) \quad P \quad(F 1 \mid C) P \quad(F 2 \mid \quad C, F 1) \quad P \quad(F 3, \ldots F n \\
& \dashv \mid C, F 1, F 2) P(F 4, \ldots F n-\mid C, F 1, F 2, F 3) \\
& =P \quad(C) P \quad(F 1 \mid C) P \quad(F 2 \mid \quad C, F 1) \quad P \quad(F 3, \ldots F n \\
& -\mid C, F 1, F 2) P(F n-\mid C, F 1, F 2, F 3, \ldots, F n-1)
\end{aligned}
$$

Dapat dilihat bahwa hasil penjabaran tersebut menyebabkan semakin banyak dan semakin kompleksnya faktor faktor syarat yang mempengaruhi nilai probabilitas, yang hampir mustahil untuk dianalisa satu persatu. Akibatnya, perhitungan tersebut menjadi sulit untuk dilakukan. Disinilah digunakan asumsi 
independensi yang sangat tinggi (naif), bahwa masing- masing petunjuk (F1,F2,...Fn ) saling bebas (independent) satu sama lain. Dengan asumsi tersebut, maka berlaku suatu kesamaan sebagai berikut:

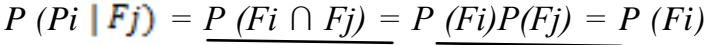

$P(F j) \quad P(F j)$

Untuk $i \neq j$, sehingga

$P\left(F i \mid C_{x} F j\right)=P(F i \mid C)$

Dari persamaan diatas dapat disimpulkan bahwa asumsi independensi naif tersebut membuat syarat peluang menjadi sederhana, sehingga perhitungan menjadi mungkin untuk dilakukan. Selanjutnya, penjabaran $P$ $\left(C \mid F 1_{v \ldots} F n\right)$ dapat disederhanakan menjadi: $P\left(C \mid F 1_{s} \ldots F\right)=P(C) P(F i \mid C) P(F 2 \mid C) P$ $(F 3 \mid C) \ldots$

$$
=P(C) \quad P(F i \mid C)
$$

Persamaan diatas merupakan model dari teorema Naive Bayes yang selanjutnya akan digunakan dalam proses klasifikasi. Untuk klasifikasi dengan data kontinyu digunakan rumus Densitas Gauss :

$P(X i=x i \mid Y=y j)=$

$$
\frac{1}{\sigma \sqrt{2 \pi}} e^{-\frac{(x-\mu)^{2}}{2 \sigma^{2}}}
$$

Keterangan :

$\mathrm{P} \quad$ : Peluang

$\mathrm{Xi} \quad$ : Atribut ke i

xi : Nilai atribut ke i

Y : Kelas yang dicari

yj $\quad$ : Sub kelas Y yang dicari

$\mu$ : Mean, menyatakan rata-rata dari seluruh atribut

$\sigma \quad$ : Deviasi standar, menyatakan varian dari seluruh atribut.

\section{METODE PENELITIAN}

\subsection{Metode Penelitian}

Metode penelitian yang dilakukan adalah metode penelitian eksperimen, dengan tahapan penelitian dalam skema penelitian seperti berikut:

- Metode Pengumpulan Data (Data Gathering)

- Metode Pengolahan Data Awal (Data Preprocessing)

- Metode yang Diusulkan (Proposed Method)

- Eksperimen dan Pengujian Method/Model (Metode Test and Experiment)

\subsection{Metode Pengumpulan data}

Penelitian ini menggunakan data nilai rata-rata rapot SMP calon peserta didik baru tahun ajaran 2014/2015 pada SMAN 2 Banjarmasin. Nilai ratarata rapor mata pelajaran IPA, IPS, Matematika, hasil Psikotest, data minat siswa, dan data hasil tes peminatan siswa.

Data yang digunakan dalam penelitian ini adalah data sekunder, meliputi data-data nilai SMP secara keseluruhan calon peserta didik baru SMA Negeri 2 Banjarmasin tahun 2014.

\subsection{Sampel Data}

Data yang didapatkan dari akademik SMA Negeri 2 Banjarmasin berupa data yang terdiri dari data rekapitulasi nilai rapor SMP, nilai Psikotest, data minat, nilai hasil peminatan serta data akhir penentuan peminatan. Data proses ini mempunyai atribut: Siswa, nilai rata-rata IPA, nilai rata-rata IPS, nilai Psikotest dan data minat. Sedangkan data hasil nilai sesudah peminatan mempunyai atribut: IPA, IPS. Jumlah sampel data keseluruhan ada 379 data siswa peserta didik baru. Data awal yang diolah terdiri dari 379 record siswa, yang terdiri dari nomor peserta, nama peserta, jurusan yang diinginkan, hasil psikotest, rata-rata rapor MTK, nilai tes MTK, rata-rata rapor IPA, nilai tes IPA, rata-rata rapor IPS, nilai tes IPS. Dari semua data ditentukan atribut proses pengolahan data awal dimulai dari kolom jurusan yang diinginkan, hasil Psikotes, Nilai MTK, nilai IPA dan nilai IPS. Data awal yang diproses kemudian ditentukan atributnya, untuk lebih jelasnya dapat dilihat tabel atribut dibawah ini:

\subsection{Metode yang Diusulkan (Proposed Method) \\ Pada penelitian ini penulis mengusulkan} metode Naive Bayes untuk membantu menentukan peminatan siswa Sekolah Mengah Atas (SMA). Metode ini dipilih karena kemampuannya untuk melakukan pengelompokkan suatu objek atau data yang belum memiliki klasifikasi, ke dalam kelas tertentu menurut kesamaan yang dimilikinya berdasarkan derajat keanggotaan dengan cara minimalisasi nilai fungsi objektifnya. Metode Naïve Bayesakan diimplementasikan pada penelitian ini. Data pada penelitian ini ada dua tipe, data nominal dan data numerik.

\subsection{Metode yang Diusulkan (Proposed Method)}

Pada penelitian ini penulis mengusulkan metode Naive Bayes untuk membantu menentukan peminatan siswa Sekolah Mengah Atas (SMA). Metode ini dipilih karena kemampuannya untuk melakukan pengelompokkan suatu objek atau data yang belum memiliki klasifikasi, ke dalam kelas tertentu menurut kesamaan yang dimilikinya berdasarkan derajat keanggotaan dengan cara minimalisasi nilai fungsi objektifnya. Metode Naïve Bayesakan diimplementasikan pada 


\section{SYSTEMIC}

Vol. 02, No. 01, Agustus 2016, 25-32

penelitian ini. Data pada penelitian ini ada dua tipe, data nominal dan data numerik.

\subsection{Eksperimen dan Pengujian}

Method/Model(Metode Test and Experiment) Algoritma yang telah dikembangkan dalam penelitian ini akan diterapkan pada ratarata Nilai Rapor SMP, Nilai Psikotest, Data Minat, Nilai Peminatan tahun ajaran 2014-2015 pada saat penerimaan peserta didik baru.

Menentukan hasil akhir peminatan merupakan hasil yang diperoleh dari rata-rata mata pelajaran peminatan yaitu rata-rata nilai IPA, rata-rata nilai IPS, rata-rata nilai Matematika, ditambahkan jurusan yang diinginkan serta dari hasil tes psikologi. Nilai minat IPA diberi label angka 1, dan nilai minat IPS diberi label angka 2. Kemudian Data ini akan digunakan sebagai data variabel ujicoba peminatan menggunakan Metode Naïve Bayes .

\subsection{Evaluasi dan Validasi}

Terdapat beberapa tahapan dalam melakukan eksperimen, yaitu (1) Melakukan pengujian klasifikasi algoritma Naive Bayes menggunakan data original yang masih terdapat data kosong (2) Mengisi data kosong menggunakan replace missing value (3) Memisahkan dataset menjadi data training dan data testing (4) Melakukan seleksi atribut untuk meningkatkan hasil akurasi (5) Mengevaluasi ketepatan klasifikasi Naive Bayes berupa evaluasi dan validasi hasil (Result Evaluation and Validation).

Tahap 1 : Melakukan pengujian klasifikasi algoritma Naive Bayes menggunakan data original yang masih terdapat data kosong. Kemudian dilakukan validasi model klasifikasi dilakukan terhadap data testing dengan teknik 10folds cross validation.

Tahap 2 : Setelah melakukan pengujian dengan data original maka selanjutnya dilakukan pengisian data kosong menggunakan replace missing value. Pengisian data kosong dilakukan untuk membuat model keputusan yang baik, sehingga harus menggunakan data yang baik pula (lengkap, benar, konsisten, terintegrasi).

Tahap 3 : Proses pemisahan dataset menjadi 2 jenis data, yakni data training dan data testing dengan menggunakan pembagian persentase dari jumlah dataset. Apabila data training yang digunakan sebanyak $10 \%$ dari dataset maka persentase data testing adalah $90 \%$. Dan apabila data training yang digunakan sebanyak $20 \%$ dari dataset maka persentase data testing adalah $80 \%$. Jumlah data training apabila dijumlah dengan data testing akan menjadi jumlah dataset tersebut.
Jumlah persentase pada data trainning nantinya akan ditentukan berdasarkan perulangan pada proses cross-validation. Contohnya, proses crossvalidation pada iterasi ke 4 dari total 10 iterasi, maka persentase jumlah data training adalah $40 \%$ dan persentase jumlah data testing adalah $60 \%$. Proses pemisahan data training dan data testing mengikuti proses $\mathrm{X}$-validation dengan jumlah iterasi mulai dari 2,3,4,5,6,7,8,9 dan 10 dan agar data yang digunakan pada proses itu tetap maka akan menggunakan dataset yang sama.

Tahap 4 : Melakukan evaluasi dan validasi hasil (Result Evaluation and Validation) dilakukan pengujian 10-fold cross-validationmaka akan mengulang pengujian sebanyak 10 kali dan hasil pengukuran adalah nilai rata-rata dari 10 kali pengujian. Kemudian pengujian performance dengan menggunakan Confusion Matrix sehingga dapat diketahui hasil akurasi.

\section{HASIL PENELITIAN}

Hasil perhitungan data peminatan siswa SMAN 2 Banjarmasin sebagai berikut :

1. Perhitungan Data Nominal

Perhitungan data nominal digunakan untuk menghitung :

- $\quad$ PA (yes|E) ; yaitu Peluang jurusan yang diiinginkan IPA dan keputusan akhirnya IPA

- PA (no|E) ; yaitu Peluang jurusan yang diiinginkan IPA dan keputusan akhirnya IPS

- PB (yes|E) ; yaitu Peluang hasilPsikotestIPA dan keputusan akhirnya IPA

- PB (no|E) ; yaitu Peluang hasil PsikotestIPS dan keputusan akhirnya IPS

Peluang-peluang tersebut dihitung menggunakan rumus :

1. $P A($ yes $\mid E)=\frac{P A\left(E_{1} \mid y e d\right) \cdot P A\left[E_{2} \mid y e s\right] \cdot P A(y e s)}{P A(E)}$

2. $P A(n o \mid E)=\frac{P A\left[E_{1} \mid n o J \cdot P A\left(E_{2} \mid n o J\right) \cdot P A(n o)\right.}{P A(E)}$

3. $P B($ yes $\mid E)=\frac{P B\left[E_{3} \mid y e s\right] \cdot P B\left[E_{4} \mid \text { yegs }\right) P B(y e s)}{P B(E)}$

4. $P B(n o \mid E)=\frac{P B\left(E_{3} \mid n \cap\right) \cdot P B\left[E_{4} \mid n o j\right) \cdot P B(n o)}{P B(E)}$

Hasil Perhitungan dari peluang tersebut adalah sebagai berikut : 


$$
\begin{aligned}
& \text { 1. } P A(\text { yes })=\frac{\text { Mmat IPA }}{\text { jumlah Data }}=\frac{267}{\text { a7g }}=0,704 \\
& P A(\text { no })=\frac{\text { Minat } I P S}{\text { jumlah Data }}=\frac{112}{\text { arg }}=0,295 \\
& P A\left(E_{1} \mid y e s\right)= \\
& \frac{\text { jumian Minat IPA dan masu } I P A}{\text { Jumiah Minat IPA }}=\frac{204}{267}=0,764 \\
& P A\left(E_{1} \mid n o\right)= \\
& \frac{\text { jumian Minat IPA wan masu } I P S}{\text { fumlah Minat IPS }}=\frac{6 \text { a }}{112}=0,562 \\
& P A\left(E_{2} \text { lyes }\right)= \\
& \frac{\text { jumlan Mrnat IPS dan masuk IPS }}{\text { jumlah Minat IPS }}=\frac{112}{267}=0,419 \\
& P A\left(E_{2} \mid n o\right)= \\
& \frac{\text { Jumian Minat IPS wan masuk UPA }}{\text { Jwhiah Minat JPS }}=\frac{0}{112}=0
\end{aligned}
$$

$$
\begin{aligned}
P A(\text { yes } \mid E) & =\frac{P A\left[E_{1} \mid y e s\right] \cdot P A\left[E_{2} \mid \text { yes }\right] \cdot P A(y e s)}{P A(E)} \\
& =\frac{0_{0} 764 \cdot 0,419 \cdot 0_{0} 704}{P A(E)}=\frac{0_{0} 225}{P A(E)}
\end{aligned}
$$

2. $P A($ no $\mid E)=\frac{P A\left[E_{1} \mid \text { no }\right) \cdot P A\left[E_{2} \mid \text { no }\right) \cdot P A(n o)}{P A(E)}$

$$
=\frac{0,562 \cdot 0 \cdot 0,295}{P A(E)}=\frac{0}{P A(E)}
$$

3. $P B($ yes $)=\frac{\text { Psikotest IPA }}{\text { Jumlah Data }}=\frac{129}{\text { a79 }}=0,340$

$$
P B(\text { no })=\frac{\text { Pgikotest IPS }}{\text { Jumiah Data }}=\frac{250}{\text { a79 }}=0,659
$$

$P B\left(E_{7} \mid\right.$ yes $)$

jumian PSIKotest IPA wan masuk IPA $=\frac{118}{190}=0,914$ jumlah Psikotest IPA

$$
P B\left(E_{p} \mid n o\right)
$$

$\frac{\text { jumlah Pgikotest IPA dan masuk IPS }}{\text { Jumiah Psikotest IPS }}=\frac{146}{250}=0,584$

$P B\left(E_{4} \mid\right.$ yes $)$

$\frac{\text { jumuan Palkotest IPS wan masuR IPA }}{\text { Jumlah prikotest IPA }}=\frac{102}{129}=0,790$

$$
P B\left(E_{4} \mid n o\right)
$$

$\frac{\text { jumian Psikotest IPS wan masuk IPA }}{\text { jumiah Pgikotest IPS }}=\frac{9}{250}=0,036$

$$
\begin{aligned}
& P B(\text { yes } \mid E)=\frac{P B\left(E_{a} \mid \text { yes }\right) \cdot P B\left(E_{4} \mid y\right.}{P B(E)} \\
& =\frac{0,914 \cdot 0,790 \cdot 0,240}{P B(E)}=\frac{0,245}{P B(E)} \\
& =\frac{0,584 \cdot 0,036 \cdot 0,659}{P B(E)}=\frac{0,013}{P B(E)}
\end{aligned}
$$

\begin{tabular}{|c|c|c|c|c|c|c|c|c|c|}
\hline Validation & 2 & 3 & 4 & 5 & 6 & 7 & 8 & & $0^{1}$ \\
\hline Accuracy & 99.4 & 99.4 & 99.4 & 99.4 & 99.4 & 99.4 & 99.4 & 39.4 & 99.4 \\
\hline Precision & 100 & 100 & 100 & 100 & 100 & 100 & 100 & 100 & 100 \\
\hline Recall & p8.8 & 88.8 & 88.8 & 38.8 & p8.8 & $p 8.8$ & 88.8 & p8.8 & 98.8 \\
\hline$A U C$ & 1.0 & 1.0 & 1.0 & 1.0 & 1.0 & 1.0 & 1.0 & 1.0 & 1.0 \\
\hline
\end{tabular}

\subsection{Evaluasi dan Validasi Hasil}

Pada tahap validasi model klasifikasi dilakukan pengujian yang dilakukan terhadap data testing dengan metode tersebut dilakukan dengan teknik cross validation dengan pengujian data mulai $2,3,4,5,6,7,8,9$ dan 10 sehingga dapat di evaluasi hasilnya dengan mengukur seberapa keakuratan akurasi yang dihasilkan dari beberapa percobaan tersebut menggunakan metode Naive Bayes.

Kemudian percobaan selanjutnya akan dilakukan pengujian algoritma Naive Bayes dengan teknik folds cross validation dengan pengujian data mulai $2,3,4,5,6,7,8,9$ dan 10 .

Tabel 1. Akurasi Nä̈ve Bayes Menggunakan Data Original

didapatkan hasil pengukuran berupa memiliki tingkat akurasi tertinggi sebesar $99.47 \%$, tingkat presisi tertinggi sebesar $100 \%$, dan tingkat recall 98.86\% dengan nilai AUC sebesar 1.000 yang termasuk kedalam kategori excellent.Untuk membuat model keputusan yang baik, harus menggunakan data yang baik pula (lengkap, benar, konsisten, terintegrasi).

Namun hasil dari berbagai percobaan yang ekstensif dan pembuktian teoritis, menunjukkan bahwa penggunaan 10-fold crossvalidation adalah pilihan terbaik untuk mendapatkan hasil validasi yang akurat. Hal tersebut karena 10-fold cross-validation akan mengulang pengujian sebanyak 10 kali dan hasil pengukuran adalah nilai rata-rata dari 10 kali pengujian sehingga dalam evaluasi hasil perbandingan performance dengan mengukur seberapa keakuratan akurasi yang dihasilkan menggunakan pengukuran 10-fold crossvalidation dan pengujian performance dengan menggunakan Confusion Matrix sehingga dapat diketahui hasil akurasi dan nilai AUC untuk menentukan hasil klasifikasi kedalam klasifikasi sangat baik, klasifikasi baik, klasifikasi cukup, GRFasifikasi buruk dan klasifikasi salah.

Kemudian hasil seleksi atribut yang didapatkan diantaranya seperti tabel dibawah ini :

Tabel 2. Daftar hasil Seleksi Atribut

\begin{tabular}{lll} 
& No & \multicolumn{1}{c}{ Atribut } \\
$\mathbf{1}$ & & Jurusan yang di inginkan \\
$\mathbf{2}$ & & Jurusan Hasil Psikotest \\
$\mathbf{3}$ & Nilai rapot MTK \\
$\mathbf{4}$ & Nilai Tes MTK \\
$\mathbf{5}$ & Nilai Rapot IPA \\
$\mathbf{6}$ & Nilai Tes IPA \\
$\mathbf{7}$ & Nilai Rapot IPS \\
$\mathbf{8}$ & Nilai Tes IPS \\
\hline
\end{tabular}




\section{SYSTEMIC}

Vol. 02, No. 01, Agustus 2016, 25-32

Dari hasil percobaan tersebut diatas maka penerapan seleksi atribut dapat meningkatkan akurasi Naive Bayes dengan penggunaan 8 atribut terpilih. Hasil tersebut kemudian digunakan untuk membandingkan seberapa besar kenaikan tingkat akurasi Naive Bayes yang dihasilkan dengan melakukan seleksi atribut.

\section{PENUTUP}

Dari hasil penelitian yang dilakukan dari tahap awal hingga pengujian, dan hasil perbandingan dapat disimpulkan bahwa model yang terbentuk dengan algoritma Naive Bayes sendiri sudah memiliki akurasi yang sangat baik yaitu sebesar $99.47 \%$ dalam mengklasifikasikan status peminatan siswa SMA.

Penelitian ini juga menghasilkan 8 (delapan) atribut terpilih yaitu Jurusan yang diinginkan siswa, Jurusan Hasil Psikotes, Nilai rata-rata Matematika siswa dari semester 1-5 ketika mereka duduk dibangku SMP, nilai tes Matematika, Nilai rata-rata IPA siswa dari semester 1-5 ketika mereka duduk dibangku SMP, nilai tes IPA, Nilai rata-rata IPS siswa dari semester 1-5 ketika mereka duduk dibangku SMP, dan nilai tes IPS.Secara umum hasil penerapan Naive Bayes mempunyai nilai akurasi yang sangat tinggi dan keunggulan dalam hal kehandalan dalam klasifikasi.

\section{DAFTAR PUSTAKA}

Peraturan Menteri Pendidikan dan Kebudayaan no.81A Tahun 2013 tentang Kerangka Dasar dan Struktur Kurikulum Sekolah Menengah Atas/Madrasah Aliyah.2013.Jakarta:Menteri Pendidikan dan Kebudayaan.

Paparan Wakil Menteri Pendidikan dan Kebudayaan Republik Indonesia Bidang Pendidikan. 2014. Konsep dan Implementasi Kurikulum2013. Jakarta: Kementerian Pendidikan dan Kebudayaan.

Wahyuningrum. 2011. Profesionalisasi Kepala Sekolah Dalam Menciptakan Iklim Kondusif di Sekolahannya. Jurnal Manajemen Pendidikan, 01 (VII), pp. 63-80.

Paparan Wakil Menteri Pendidikan dan Kebudayaan Republik Indonesia Bidang Pendidikan. 2014. Konsep dan Implementasi Kurikulum2013. Jakarta:
Kementerian Pendidikan dan Kebudayaan.

Asosiasi Bimbingan dan Konseling Indonesia. 2013. Panduan Khusus Bimbingan dan Konseling Pelayanan Arah Peminatan Peserta Didik pada Satuan Pendidikan Dasar dan Menengah (SD/MI, SMP/MTS/SMPLB, SMA/MA/SMALB dan $S M K / M A K)$. Jakarta:ABKIN.

Amundson, N.E., et.al., 2010. Career Decisions From the Decider's Perspective. The Career Development Quarterly, 58, p. 336.

Perry, N., VanZandt, Z., 2006. Focus On The Future A Career Development Curriculum For Secondary School Students. New York: Debate Press.

Turner, S.L., Conkel, J.L., 2010. Evaluation of a Career Development Skills Intervention With Adolescents Living in an Inner City. Journal of Counseling dan Development, 88 , p. 457.

Kementerian Pendidikan dan Kebudayaan.2013.Model Penilaian Hasil Belajar Peserta Didik. Jakarta:Menteri Pendidikan dan Kebudayaan.

Hanafi, P., 2010. Analisis Daya Saing Perguruan Tinggi di Indonesia Berdasarkan Webometricks dengan Literatur Batak Sebagai Nilai Tambah Daya Saing Perguruan Tinggi dalam Penelusuran Online. Universitas Sumatera Utara.

Grainer, R., 2005. Physical Research Abstracts, 7 (11076) SRef-ID: 1607-7962/gra/EGU05A-11076 @ European Geosciences Union.

Subbalakshmi, G., et.al., 2011. Decision Support in Heart Disease Prediction System using Naive Bayes. Indian Journal of Computer Science and Engineering, 2 (2), p. 170.

Bahar. 2011. Penentuan Jurusan SMA dengan Fuzzy C-Means. UDINUS Semarang.

Asmiana, Z., Bu'ulolo, F., dan Siagian, P., 2013. Penggunaan Sistem Inferensi Fuzzy Untuk Penentuan Jurusan di SMA Negeri 1 Bireuen. Saintia Matematika, 1 (3) pp. 233-247. 
Hidayah, N., 2013. Klasifikasi Penjurusan Program Studi Sekolah Menengah Atas dengan Algoritma Nä̈ve Bayes Classifier pada SMAN 1 Subah. UDINUS Semarang.

Fitriyani. 2012. Sistem pendukung keputusan penjurusan SMA Menggunakan Metode AHP. Seminar Nasional Teknologi Informasi dan Komunikasi Terapan 2012. Semarang, 23 Juni 2012.

Swastina, L., 2013. Penerapan Algoritma C4 .5 Untuk Penentuan Jurusan Mahasiswa. Gema Aktualita, 2 (1), pp. 93-98.

Reza, A., 2015. Penentuan Jurusan Siswa Sekolah Menengah Atas Disesuaikan Dengan Minat Siswa Menggunakan Algoritma Fuzzy C-Means. UDINUS Semarang.

Departemen Pendidikan Nasional. 2006.Petunjuk Teknis Pemberlakuan Kurikulum Tahun 2006 dan Kurikulum 2013 pada Sekolah Jenjang Pendidikan Dasar dan Pendidikan Menengah. Jakarta: Direktorat Jenderal Pendidikan Dasar dan Pendidikan Menengah.

Peraturan Pemerintah No.32 Tahun 2013 tentang Perubahan atas Peraturan Pemerintah No.19 tahun 2005. 2013. Standar Nasional Pendidikan. Jakarta: Direktorat Jenderal Pendidikan Nasional.

Han, J., Kamber,M.,2006. Data Mining Concepts and Techniques. USA: Morgan Kaufmann Publishers.

Bellazzi, R., Zupan, B., 2006. Predictive Data Mining in Clinical Medicine: Current issues and Guidilines. International Informatics, 11 (006), p.3.

Witten, I.H., et.al., 2011. Data Mining Practical Machine Learning Tools and Tehnniques. USA: El Savier Inc.

Bramer, M. 2007. Principles Of Data Mining. London: Springer-Verlag London Limited.

Larose,D. T.,2006. Data Mining Method and Models. Canada: A John Willey and Sons, Inc.
Bramer, M. 2007. Principles Of Data Mining. London: Springer-Verlag London Limited.

Larose,D. T.,2006. Data Mining Method and Models. Canada: A John Willey and Sons, Inc.

Dale, A.I.1999.A History Of Inverse Probability. New York: Springer.

Gorunescu, F. 2010. Data Mining Concepts, Models, and Techniques. Berlin: Springer. 